\title{
Max Lane
}

Decentralization \& Its Discontents. An Essay on Class, Political Agency, and National Perspective in Indonesian Politics. Singapore: ISEAS, 2014, 122 pp. ISBN: 9789814519731. Price: USD 27.04 (hardcover).

Indonesia's supposed 'bing bang' decentralization has raised considerable academic attention and heated debate since it began in 1999. With the intellectual and material support from international donors, the transition from an authoritarian, centralized state to a democratic, decentralized state was considered swift and smooth. Nevertheless, after 15 years' implementation of regional autonomy, the effect of decentralization on economic development is dubious or negligible at best, as claimed in many literatures. Worse still, critics of the process claim that decentralization only opened up opportunities for local elite capture (see Hadiz, 2010), while the local political and economic dynamic remains largely unchanged, which is neither conducive to boost the national economic development nor to improve people's average living condition. The puzzle raised from the scholarly frustration is, why does Indonesia's decentralization so far turn out to be unsuccessful in accelerating national development, as it was expected by domestic technocrats and international donors alike?

Among the many academic works seeking to explain how the now 15 year process has unfolded, Max Lane's new book Decentralization \& Its Discontents. An Essay on Class, Political Agency, and National Perspective in Indonesian Politics stands out for its novel perspective in analyzing the unsatisfactory outcome of decentralization, and provides an alternative approach to tackle the enduring problem of Indonesia's underdevelopment. He argues that the reason why decentralization has not achieved the desired result is the lack of a national political agency created on a solid class basis. This agency would set a developmental strategy on the national level, and provide coordination across the archipelago to tackle the unevenness and mobility problems intrinsically embedded in this highly heterogeneous country.

In the first chapter, Lane argues that the decentralization is a result of two processes. The first is the end of the Soeharto regime and the subsequent fall of crony capitalists supported by the authoritarian regime. Crony capitalists were the major social class, which may have the incentive to oppose decentralization because of their potential business interests on the national level, but then they were not capable of steering the political course. The second process was the technocrat interregnum led by Habibie, who showed a welcoming attitude to international donors and received material and policy support from the latter, who acted as major proponents for decentralization reforms world-wide.

(C) SONG XUE, 2016 | DOI: 10.1163/22134379-17201011

This is an open access article distributed under the terms of the Creative Commons 
The second chapter discusses the political economy behind the consolidation of regional autonomy. Indonesia's long-time economic underdevelopment has not fostered the emergence of a national capitalist class. Furthermore, the sudden fall of Soeharto ended the crony capitalism. The conglomerates did not flock into the same political cluster; instead, they formed various political parties to protect their interests, which weakened the political power of the national capitalist class. These two factors have provided opportunities for the growth of local capitalists, who have been the major beneficiaries and supporters of decentralization.

The following chapter analyzes decentralization and its discontents. The major flaw in Indonesia's decentralization reform has been its poor performance of economic growth. The author generally agrees with Pepinsky and Wihardja's (2011) conclusion, arguing that decentralization was not able to tackle the serious unevenness and mobility problems faced by this country with substantial heterogeneity. He concludes that only a national agency acting in the interest of the majority of people could provide a national developmental strategy, and coordinate across regions.

The fourth chapter elaborates the potential direction of the aforementioned national agency. On the one hand, local capitalists, represented by Joko Widodo, are ruled out as the proper political agency to maximize the potential of decentralization reform, because they tend to demobilize civil society by playing the role of a patient listener and manipulating the patron-client network. On the other hand, the author sees great potential in the reinvigorated labor movements and the activities of labor unionists in recent years, since they are nationally based and represent the majority of the country's social class. Endowed with the two favorable and essential factors, a national agency may arise from labor movement to lead the country's strategic development in the future.

This book is both insightful and thought provoking, leaving much room for closer observation of the labor movement and a thorough analysis of the political dynamics generated by decentralization. First, Lane does not envision how the labor movement will assume the role of creating a national agency representing the interests of the mass. He mentions that some prominent unionists have cooperated with existing political parties in local elections, but there has not been affirmative signs of the emergence of a new socialist workers party. It is challenging and intriguing to imagine how the labor movement might find a way to merge with the current political structure. Second, he does not fully elaborate why local capitalism would not assume the role of national developer. It is implied between lines that local capitalists may deem local interest as more important than national interest. As with labor unions, lacking 
a national agency is also a disadvantage for local elites. However, the role of local capitalists deserves a more detailed analysis because they are the major beneficiaries of decentralization and are becoming increasingly prominent on the national political scene. Another point of uncertainty is how local capitalists will react to the surging labor movement. Will they cooperate with conglomerates on the national-level politics, as they are doing right now, or side with labor?

Students of Indonesia's regional autonomy would find this book intriguing for its rare perspective of a social class analysis and detailed account of Indonesia's first attempt at decentralization. The book also serves as a prologue to help us make sense of the ongoing labor movement in Indonesia and its implications.

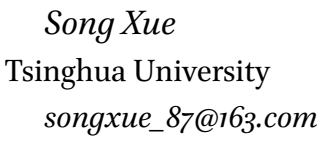

\section{References}

Hadiz, Vedi R. (2010) Localising Power in post-authoritarian Indonesia. A Southeast Asia Perspective. Stanford: Stanford University Press.

Pepinsky, Thomas B., and Maria M. Wihardja. (2011) 'Decentralization and economic performance in Indonesia', Journal of East Asian Studies 11.3: 337-371. 